\title{
Restrictions on Congregational Prayers and Negotiations on Religious Freedom during Pandemic in Indonesia
}

\author{
Alamsyah M Dja'far
}

\begin{abstract}
This article discusses the policy of restricting religious rights or beliefs during the pandemic time in Indonesia. Most studies presume that restriction policy is in line with the principles and rights of religious freedom. These studies have not much directed towards answering how the restriction on the worship right, such as congregational prayers, able to accommodate and negotiate various rejections and neglects by some Islamic communities. This paper comes with the idea that policies to restrict congregational prayers should not be uniform but provide several alternative approaches. This approach needs support from central and local authorities negotiating abilities. The main research data came from the policy documents of the central government and provincial government. Secondary data came from media coverage and relevant literature. This study found that restrictions in the early days of the pandemic applied uniformly in the form of the absence of congregational prayers during the lockdown period. The policy does not provide alternatives such as still allowing it by establishing health protocols.
\end{abstract}

\section{Keywords}

Worship restrictions; negotiations; religious freedom; government; COVID-19

\section{Introduction}

Like many countries on various continents, Indonesia has also faced the coronavirus disease (COVID-19) outbreak since March 2020. This pandemic has an impact on almost all areas of people's lives, including religious life. The Central Government has taken several preventive and handling steps, including by issuing regulation about Large-Scale Social Restrictions in the Context of Accelerating Handling of Corona Virus Disease 2019/ Peraturan Pemerintah Republik Indonesia Nomor 21 Tahun 2020 (hereafter referred to as PP No. 21 Tahun 2020). This decision issued after the Indonesian government officially announced the coronav-

\footnotetext{
Alamsyah M. Dja'far is a Master candidate at School Government and Public Policy Indonesia. For nearly 10 years, he has been involved in working on issues of freedom of religion and belief and advocating for the rights of religious minorities in Indonesia at Wahid Foundation.
}

\section{Corresponding Author:}

Alamsyah M. Dja'far, School Government and Public Policy Indonesia, Bogor, Indonesia. Email: a.djafar@sgpp.ac.id 
irus disease case on March 2, 2020 (PP 21 Tahun 2020, 2020).

This policy regulates the authority of the central government and local governments to restrict community activities, which include religious activities in worship places such as mosques, churches, temples, shrines, pagodas, and others. This policy then becomes the basis for regional leaders to issue similar policies in their respective regions. This policy generally has public support, including the religious community in Indonesia. However, the policy of restricting congregational prayers (hereafter salat berjamaah) also did not run successfully. Some residents still ignore and even oppose it. Cases of neglect and opposition, for example, occurred in Jakarta, West Java and other areas (Kompas 2020b; Suara 2020; Tempo 2020). Several parties such as dozens of people acting on behalf of regional the regional Indonesian Muslim Intellectuals Association (Ikatan Cendekiawan Muslim Indonesia/ ICMI) and political figures such as Hidayat Nurwahid stated that the implementation of the policy was discriminatory (Antaranews 2020; CNN Indonesia 2020).

This study departs from the view that the government is obliged to protect public health. To avoid exposure to COVID-19, the worship right such as salat berjamaah can be limited. Restrictions are guaranteed in the Undang-undang Dasar 1945, Undang-undang Nomor 391999 about Human Rights (hereafter referred to as UU HAM) dan Undang-undang Nomor 12 Tahun 2005 about The Ratification of International Covenant on Civil and Political Rights/Kovenan Internasional Tentang Hak-Hak Sipil dan Politik (hereafter referred to as UU KIHSP). Some studies on religious rights and COVID-19 have examined whether the restriction policy is in line with the principle of limiting human rights or not (Tobroni 2020; Widyawati et al. 2020; Yahman and Setyagama 2020). In recent years, these studies have been the focus of many experts in many countries (Flood et al. 2020; George 2017; Glover et al. 2020; Istratii 2020; Spadaro 2020).

In the Indonesian context, studies on religious rights and COVID-19, still have not discussed many strategies and steps for implementing restriction policies which more careful and accommodating to various emerging religion aspirations. This policy should be able to provide room for negotiation amid uncertainty. This paper seeks to fill this gap. The author attempts to answer two key questions. First, to what extent the policies of the central and local governments in limiting the worship right during the COVID-19 outbreak fulfil the principle of limitation in human rights? Second, what should the government do to make this policy more in line with human rights restriction? This article are expected to contribute to the development of the studies of religious rights in Indonesia and legal restrictions according to international human rights instruments and domestic law. Also, the results of this study are useful to encourage improvements in the quality of the COVID-19 outbreak prevention policies and religious rights at the central and local government levels.

The discussion structure of this paper consists of five main parts. The first part is a literature review on the restrictions of religious rights during a pandemic time, and the research strategies used in this article. The second part discusses how the principles of limiting the right to worship such as salat berjamaah are 
guaranteed in international human rights instruments and domestic law in Indonesia. The third part describes the case of the PSBB Policy by the central government and two provincial governments (DKI Jakarta and West Java). The fourth and fifth sections contain discussion and analysis of how the content and implementation of policies on restrictions on salat berjamaah should accommodate and negotiate various objections and even rejection of the policy.

\section{Literature Review}

\section{Restrictions on Religious Rights during the Pandemic}

Restriction on religious freedom due to public health reasons during the pandemic (COVID-19) has become a study that has continued to develop in recent time (Flood et al. 2020; Spadaro 2020). This study generally refers to the previous discussion regarding the principles of legal restriction based on human rights instruments as contained in International Covenant on Civil and Political Rights (ICPPR), Siracusa Principle ${ }^{1}$, and domestic laws of each counties (Meier et al. 2020; Plessis, 2020). One of the key questions in the issue of restricting the worship right in worship place is whether the restrictions of several countries to prevent COVID19 are in line with the principles in human rights instruments and the constitution. Some stated that these policies were valid and in line with international instruments such as the ICCPR and the Siracusa Principle and the domestic laws of each country (Flood et al. 2020; Marshall 2020).

On the other hand, several studies have stated that the restrictions imposed by several governments in several countries such as Greece, the United States, Iran violate or have the potential to violate religious rights. This study emphasizes that the worship right in a worship place is a basic right that is guaranteed and respected by the state even amid a pandemic even though it still applies health protocols and is carried out without discrimination to types of associations or other parties (George 2017; Glover et al. 2020; Istratii 2020). However, those who state that restricting the right to worship by closing their house is a violation not because restrictions in the name of health are a violation, but rather because of problematic methods and mechanisms of restriction. Nor does it mean that those who agree with the restrictions ignore potential violations of religious rights in the implementation mechanism (Glover et al. 2020; Marshall 2020).

In Indonesia, on the one hand, developed studies mostly view restrictions on the worship right by the Indonesian government in line with the principle of restriction in human rights and laws and regulations (Tobroni 2020; Widyawati et al. 2020; Yahman and Setyagama 2020). This has also developed in a number of statements by representatives of state institutions such as National Commission on Human Rights (Komnas HAM) or experts in the mass media (VOA Indonesia 2020).

${ }^{1}$ Siracusa Principles are principles regarding provisions on limitation and derogation of rights which are stipulated in the International Covenant on Civil and Political Rights (ICCPR). These principles were produced by a group of international jurists who met in Siracusa Conference, Italy, April and May 1984. 
On the other hand, there are several studies that explained the Indonesian government's in implementing policies on handling COVID-19 violate human rights and problematic (Mietzner 2020; Wiratraman 2020). However, the cases that highlighted were mostly issues outside of religious freedom, namely freedom of expression, opinion, and violations during the pandemic period such as the case of spreading hoaxes.

In short, there are little studies that have looked further on how policies to restrict religious rights should be implemented to reduce potential violations of religious rights and other rights, covering how the central and local governments accommodate and negotiate various aspirations of the community, including those who reject the policy. Among these rare studies is research of Suhadi, et al., regarding the limitation of religious rights during the COVID-19 outbreak (Suhadi et al. 2020). Although it describes the principles that must be followed when implementing policies, this study does not focus much on how the government should take negotiation and accommodation steps.

\section{Methods}

This research used content analysis method towards the policies of the Central Government, DKI Jakarta Provincial Government, and West Java Provincial Government regarding Pembatasan Sosial Berskala Besar (Large-Scale Social Restrictions). This analysis is considered appropriate for understanding the issues in these documents because it provides a way to simplify and reduce large amounts of data into specific sections or themes such as attitudes, views, values, or assumptions of policymakers or authors (Marvasti 2004, 91). Those policies documents are PP Nomor 21 Tahun 2020, Pergub DKI No 33 Tahun 2020, and Pergub Jabar No 27 Tahun 2020.

This study also used fatwa documents by Islamic organizations in Indonesia related to COVID-19, the results of studies on the fulfilment of religious and human rights during the PPSB, and news from online media about religious freedom and COVID-19 policies in Indonesia. In online media, data collection carried out using a search engine by selecting keywords such as "hak beragama dan COVID-19 (religious rights and COVID-19)", "pembatasan salat berjamaah (restrictions on salat berjamaah)" and "imbauan ibadah di rumah (exclamations to worship at home")". The data is then analyzed using the approach of the right to religion or belief. Because this restrictions cannot be separated from the context of the constitution and law in Indonesia. This paper also analyze it by looking at its compliance with the UUD 1945, especially the pasal (article) regulating religious rights and their restrictions.

\section{Results and Discussion}

\section{Salat Berjamaah and Restrictions on Religious Rights}

The worship right is one type of manifestation of the religious freedom. This right includes various ritual activities and religious ceremonies, also other 
related activities, such as establishing worship places, the use of ritual objects and religious symbols, and the celebration of holy days (Human Right Committee 1993). This understanding does seem broad. This right includes rights which are different rights that can be distinguished from the worship right but are interrelated. In the practice of monitoring religious freedom in Indonesia and internationally, the worship right is differentiated from the right to establish worship places, religious symbols, and teaching and disseminating religious materials (Setara Institute 2019, 17-18; Wahid Foundation 2020, 52-54)

In Islam, congregational prayers in a mosque, mushalla, or in an open place such as a field is one example of the right to worship. According to the majority of classical scholars, congregational law is highly recommended (sunnah muakkad). Some say it is obligatory. Among Muslims, the hadith that states "salat berjamaah (salat in congregation) more important than prayer itself by twentyseven degrees fold" is very popular (Bakar 2009). Several types of prayers condemned as invalid without congregational, namely salat Jumat and two salat Eid. While the prayer whose law is sunnah in a congregation - and if performed without a congregation is still declared valid - is the salat lima waktu (salat five times a day) and salat Tarawih that usually performed on the nights during Ramadan. If the congregation salat lima waktu, the congregation means performed by two or more people, in the salat Jumat, the number required is at least forty people (Rasjid 2018, 124).

Freedom of religion or belief itself is one type in the human rights category besides other civil and political rights such as freedom of expression. This right formally assured in dozens of international human rights laws, which consist of treaties of declarations, guidelines, recommendations, and principles that in conjunction set of international human rights standards (OHCHR 2000). In several international instruments, the religious right regulated in article 18 of the Declaration of Human Rights. This right covers an area known as internal freedom (forum internum), which includes the right to choose a religion and change religions; and external freedom (forum externum), including the right to manifest religion or belief such as teaching, practice, worship, and observance (Scolnicov 2011, 12).

Religious freedom also has strong support in the UUD 1945 and several laws and regulations under it. Some of them are UU No. 39 Tahun 1999 concerning Human Rights and UU No. 12 Tahun 2005 concerning ratification of The International Covenant on Civil and Political Rights. Like the right to religion in other external forums, the implementation of the worship right can be restricted, one of which due to public health considerations. In the UUD 1945, the restriction of human rights contained in Pasal 28J (2). This pasal (article) enacts that every person is obliged to submit to the restrictions under the following conditions: first, it is enacted by law; second, solely to guarantee recognition and respect for the rights and freedoms of others; third, to fulfil fair demands by considerations of moral, religious values, security and public order in a democratic society.

This Pasal does not regulate restrictions on health considerations. However, restrictions on health bases are listed in the Pasal 18 (3) of the KIHSP, 
which states that freedom to practice and determine one's religion or belief can only be restricted by two conditions. First, it restricted by regulations based on law. Second, it necessary to protect public safety, order, health, or morals, or the fundamental rights and freedoms of others (United Nation, 1966). This restriction effort is also following the mandate in Pasal 28H (1) of the UUD 1945 which states, "Every person has the right to live in physical and mental well-being, to have a place to live, and to have a good and healthy living environment and the right to obtain health services." Avoids exposure to the COVID-19 outbreak is part of the right to a proper and healthy environment and to obtain health services.

In the context of human rights, the application of these restrictions further enacted in the Siracusa Principles. This document enacts that the contents of the law to restrict human rights must be proportional and for specific purposes, not arbitrary or unreasonable, not imposed for discriminatory purposes (AAICJ 1985; Dja'far et al. 2016; Suhadi et al. 2020). The Siracusa Principles also emphasize that if the government is obliged to take steps to overcome any serious threat to the health of the population or individual member of the community, it must specifically aim at preventing disease or injury or providing care for those who are sick and injured. These measures should pay attention to international health regulations set by the World Health Organization (WHO) (AAICJ, 1985).

The main instrument on health issues is the International Health Regulations 2005 (Manchin and Carr 2020; Organization World Health 2008). WHO has also published two documents: Public Health for Mass Gatherings: Key Considerations (World Health Organization 2015) and Key planning recommendations for mass gatherings in the context of the current COVID-19 outbreak (World Health Organization 2020a). These documents contain more clearly the basis and steps for consideration in restricting, modifying, delaying or even canceling mass gatherings, including pray at worship places. One substantial step to consider is a comprehensive risk assessment that must be carried out at the initial planning stage, reviewed periodically during planning, and updated immediately before submission to the operational phase (World Health Organization 2015, 16-17).

The WHO Recommendation Document for handling Coronavirus contains three substantial steps in planning mass meeting activities: planning, implementation, and post-activity (World Health Organization 2020a). At these phases, activity implementers need to pay attention to types of activities, demographics, environmental factors such as location, access, political factors, coordination among various stakeholders, and risk mitigation. WHO document also mentions two terms of communication in crises such as pandemics: risk communication and crisis communication. The first type of communication is more continuous, systematic, proactive and engaging, while the second has a controlcommand style (World Health Organization 2015, 66). This communication is necessary to prevent various rejections or unexpected actions when the policy implemented. 


\section{PSBB Policy and Various Reactions}

As of December 19, 2020, the number of Indonesian citizens infected reached 657,948, recovered 536,260 people and died 19,659 (Komite Penanganan COVID-19 dan Pemulihan Ekonomi Nasional 2020). Based on the cumulative number of people infected, Indonesia ranks 19th in the world (World Health Organization 2020b). Responding to the impact of the COVID-19 outbreak, in addition to issuing Keputusan Presiden Nomor 7 Tahun 2020 on Gugus Tugas Percepatan Penanganan Virus Corona (Corona Virus Acceleration Handling Task Force)-hereafter referred to as Kepress 7 Tahun 2020, the Central Government also issued PP 21 Tahun 2020.

PP 21 Tahun 2020 conducted March 31, 2020, contains 7 pasal (articles). One of the purposes is to authorize the local government to take at least some measures including facilitating schools and workplaces; restriction of religious activities; and restriction activities in public places or facilities. Pasal 2 Ayat (1) and Ayat (2) states that the steps taken by the local government to implement PSBB can only be done after obtaining the approval of the minister who conducts government affairs in the area of health based on considerations such as epidemiological considerations or the magnitude of the threat.

After PP 21 Tahun 2020 was signed, two provinces and 16 districts/cities issued PSBB policies as of April, 21 $1^{\text {st }}$ (Tagar.id, 2020). This number increased to a total of 74 cities/regencies as of May 31, 2020 (Suhadi et al., 2020, pp. 40-42). DKI Jakarta is the first local government to receive PSBB approval. DKI Jakarta Governor Anies Baswedan issued Pergub DKI No 33 Tahun 2020, on April 9, 2020. This regulation arranges that places of worship are the targets of the temporary suspension policy. Pasal 11 Ayat (1) and (2) states that further religious activities carried out in their respective homes (Biro Hukum Provinsi DKI Jakarta 2020). This regulation does not prohibit transporting people by public transportation, train or other modes of transportation of goods. According to Pasal 18 Ayat (7), vehicles can proceed with the requirements, such as, the limited number of people maximum $50 \%$ of the carrying capacity or operating hours curfew under the DKI Jakarta government regulation and/or related agencies, or maintaining a minimum one-meter distance between passengers (Biro Hukum Provinsi DKI Jakarta 2020).

Pergub Jawa Barat No 21 Tahun 2020 signed by Ridwan Kamil is not much different. The document, which signed on April 12, 2020, regulates guidelines for restricting PSBB in Bogor City, Bogor Regency, Depok City, Bekasi Regency and Bekasi City. As stated in Pasal 9 and 10, activities at worship places are temporarily suspended (Pemprov Jawa Barat 2020). With the issuance of the two regional head regulations, salat berjamaah in more than 130 mosques are prohibited. Residents can only pray in their respective homes. Pasal 10 Ayat (1) Pergub DKI 33 No. 2020, for example, states that every person who violates will be subject to administrative penalties without fines by the Civil Service Police Unit (Satuan Polisi Pamong Praja/Satpol PP) and can be accompanied by the police. However, in another article, this regulation provides a fine of Rp. 100.000 to Rp. 10 million if found that more than five people are in a public place or facility.

Support for this PSBB restriction policy came from many religious 
organizations. In the Islamic community, Central Board for the Indonesian Ulema Council (Majelis Ulama Indonesia/ MUI) supports PSBB restriction policy. MUI issued Fatwa No. 14 Tahun 2020 concerning Penyelenggaraan Ibadah dalam Situasi Wabah COVID-19 (Implementation of Worship in the COVID-19 Outbreak Situation). One of the recommendations in this fatwa is to demand Muslims to support and comply with government policies that isolate and treat convicts of COVID-19 so that the spread of the virus can be prevented (MUI Pusat 2020).

Thus, restrictions on salat berjamaah for health reasons due to the COVID19 outbreak have legitimacy based on the UUD 1945, UU No. 391999 concerning Human Rights, and UU No. 12 Tahun 2005 concerning KIHSP ratification. The state, especially the government, must protect public health. It's just that the implementation of these various policies must remain responsive, accommodating, and provide space for negotiations amid uncertainty. Without these efforts, the implementation of a restriction policy could potentially violate religious or other rights.

In implementing restrictions, not all local government policies run successfully. Some Muslims in Jakarta and West Java, ignore and reject the policy of prohibiting salat berjamaah (Kompas 2020b, 2020c). Several days after issuing the PSBB, the DKI Government noted that around 40 mosques still allowed salat tarawih berjamaah (Tempo 2020). In West Java, more than ten large mosques still hold salat jumat (Detik 2020). In East Jakarta, some teenagers even damaged the fence of residents' houses in Jati Village, Pulogadung. The action, which took place in the early hours of April 24, 2020, was triggered by an uploaded a video of salat tarawih in the area of village(Liputan 6 2020). Some people in Bandung forced the Dewan Kemakmuran Masjid Raya of Bandung to take down banners containing the call to prayer at home. This incident was widespread on social media, March 20, 2020 (Suara 2020). In Parepare, South Sulawesi, a sub-district head was even reported to the police under the blasphemy law for trying to eliminate salat jumat at the Ar-Rahman Mosque in Ujung Sabbang Parapare, April 17, 2020 (Kumparan 2020).

Hundreds of people who claimed to be administrators of the regional Indonesian Muslim Intellectuals Association (ICMI) at the end of April 2020 also expressed rejection of the central government policy. They sent an open letter to President Jokowi asking to open worship places for use during the COVID-19. The letter stated that social restrictions in worship places contradict the preamble to the UUD 1945 and the $1^{\text {st }}$ principle of Pancasila. As a solution, the government can provide health check facilities there, and the ban only imposed on unhealthy people (CNN Indonesia 2020).

The attitudes and behaviour of citizens towards the COVID-19 Outbreak Management Policy are closely related to the background of political behaviour, belief in the government's ability to handle COVID-19, employment status, income, education, religion, and gender (Kuipers et al. 2020; Mujani and Irvani, 2020). According to this study, the number of voters for the Joko Widodo-Ma'ruf Amin pair compared to the Prabowo Subianto-Sandiaga Uno pair in 2019 agreed with the PSBB gender (Kuipers et al. 2020, 9; Mujani and Irvani 2020, 233-234). The 
study of Mujani and Irvani (2020) and Kuipers et al. (2020) which is based on the results of a survey by Saiful Mujani Research and Consulting (SMRC) on public attitudes and behaviour related to the COVID-19 outbreak, April 23-26, 2020, seems to provide an analytical tool to answer why fatwas or views of religious figures regarding restrictions on salat berjamaah are partially neglected people at the grassroots. For example, Pabbajah et al. (2020) shows that these fatwas not followed by some people and are considered a symptom of the de-authorization of the ulama in preventing the CIVID-19 outbreak (Pabbajah et al. 2020, 267).

In the months after the pandemic began, the central and local governments adopted laxer policies. On May 29, 2020, the Minister of Religion of the Republic of Indonesia issued "Panduan Penyelenggaraan Kegiatan Keagamaan di Rumah Ibadah Dalam Mewujudkan Masyarakat Produktif dan Aman COVID di Masa Pandemi (Guidelines for Organizing Religious Activities in Houses of Worship in Realizing a Productive and Safe Society for COVID in the Pandemic Period)". This guideline allows people to pray in worship places with due observance of health protocols. During the transitional PSBB period that was issued by the Governor of DKI Jakarta in early June, mosques could start carrying out activities by applying social distancing. MUI DKI Jakarta issued Fatwa Nomor 05 Tahun 2020 concerning Hukum dan Panduan salat Jumat Lebih dari Satu Kali pada Saat Pandemi Covid19/Law and Guidelines for salat Jumat More Than Once During the Covid-19 Outbreak(Kompas 2020a).

Outside DKI Jakarta and West Java, some religious fatwas in the regions have attempted to regulate Muslims to pray with various notes and conditions. For example Maklumat and Tausyiah MUI Kota Padang No. 002/MUIPDG/V/2020. One of the contents is the permission to hold salat jumat and salat tarawih berjamaah at the mosque requires written permit from city government or City Task Force and the Health Service. Letter (No. 23/MUI/JTM/V/2020) with the similar tone conveyed by the Pengurus MUI Jawa Timur to the Governor of East Java, the Regent of Gresik, the Regent of Sidoarjo and the Mayor of Surabaya. MUI asked the local leader to make concessions for the Muslim community to carry out salat berjamaah at worship places. Of course, on the condition implementing health protocols.

\section{Various Alternatives to Restrict the Worship Right}

As a new global phenomenon experienced by the world community, COVID-19 affects almost all aspects of human life. That way, the level of complexity in handling and preventing it is getting higher. The policies were taken, not only need to be careful, but also have to consider many factors such as politics, culture and religion. It is not surprising that the impression appears that the Indonesian government is stuttering in facing this global epidemic. However, this is not just a symptom of Indonesia. Most of the countries in the world face similar challenges. For example, in America, Greece, and Italy, the policy of restricting worship is opposed by some citizens and considered as a violation of the rights of other religions (Glover et al. 2020; Istratii 2020).

Something that stands out from the response and the method various 
countries handling this pandemic, namely the policies and response in many countries, both in the region and internationally, are carried out with various strategies and approaches. According to Travica (2020), there are three policy models adopted by many countries in the world to prevent COVID-19: restrictive, permissive, and hybrid or mixed (Travica 2020, 9-11). China and several countries in Africa and Asia use a restrictive style. This approach is more assertive. The strategy was implemented with a variety of policies, including deploying the police, even the army. America, the UK and most EU countries use a permissive strategy. This policy is more lenient. For example, policies that may converge with some requirements. Meanwhile, South Korea, Hong Kong, Singapore, Taiwan, and Japan use a hybrid approach or a mixture of restrictive and permissive approach at once (Travica 2020,11).

These approaches, according to Travica, reflect the cultural and political context of each country. In countries with strong communal cultures, a permissive approach may be less effective. This approach is suitable in liberal countries that emphasize individual rather than collective rights. Restricting religious services to all religions or beliefs effective in the context of collective culture, but requires more careful and different policies (Travica 2020). Ferrière's study (2020) also describes the variety of restrictions on the worship right by the governments in 27 states of the European Union member and the United Kingdom (Ferrière 2020). The restriction policies grouped into four levels: very strict, strict, moderate, low. Countries such as Germany and Britain, for example, impose very tight restrictions by limiting worship in public places and public religious celebrations. Whilst Italy and Finland imposed tight restrictions by suspending public celebrations but allowing private prayers accommodated at worship places. Sweden and the Netherlands adopted a moderate approach which allowing public celebrations to take place as long as they do not exceed the maximum number of participants. A small group of European Union countries such as Spain and Hungary have opted for low-level restrictions (Ferrière 2020).

In the early days of the pandemic, Indonesia preferred a "very tight" approach under the Ferrière category or a "restrictive" approach under the Travica category. This pattern tends to enact a single policy without providing any options. The PSBB policies of Jakarta and West Java Governors interpret the restrictions in PP 21 Tahun 2020 only by eliminating pray in worship places. Although on the paper the absence of salat berjamaah only enacts to regions that have implemented the PSBB, in many areas, this policy carried out by regions that have not held PSBB.

Referring to PP 21 Tahun 2020, restricting praying in worship places such as salat berjamaah, actually still provides options for various other policies such as continuing to do so in areas with low risk based on the decision of the local authorities. Moreover, the term used is "restriction". Steps to continue to provide options for the implementation of worship with social distancing and strictness are still in line with the guidelines and policies set out in WHO documents. Over time, issued policies such as the PSBB transition policy in DKI Jakarta and the issuance of a Surat Edaran Menteri Agama, show that restrictions do not necessarily mean 
simply the absence of salat berjamaah in worship places. Restriction can still be done by continuing to pray in a congregation with certain conditions. With this kind of change, could it be said that the restriction in the form of absence at that time was a violation of the religious right because it did not provide other options?

By providing various alternatives to restricting the right to pray in a congregation, the government can send a strong message respecting the citizens religious right. This option is also useful as an anticipation step in reducing rejection actions and even politicizing issues as they have already happened. Local governments, for example, can make these various policies as arguments that policies are discriminatory. Because while they prohibit worship, government allow public transportation activities such as the busway in Jakarta and West Java, including the opening of malls in the region. Those restriction alternatives can also accommodate the religious community who feel that salat berjamaah such as the salat jumat and salat tarawih must still be engaged.

Policies that provide a variety of policy options and alternatives with rapid changes, still considering prudence, require policy agility. This policy can be sustained and taken by continuing to provide the best evidence and continually being readjusted to avoid negative impacts or the potential to interfere with the basic rights other than religious right such as the right to expression or the right for information (Flood et al. 2020, 887). Of course, implementing these various options requires more resources as well as careful planning, especially conducting an open and accountable risk assessment.

\section{Negotiating Worship Right}

Providing various alternatives to restricting the worship right, does not fully guarantee its successful implementation in the reality. This success determined by many factors. Apart from political and religious factors, the government's ability to negotiate and communicate during the crisis also determines success (Flood et al. 2020, 894; Spadaro 2020, 323). The political risk faced by the officials and the bureaucracy in the regions due to this policy implementation is potential for community resistance, especially from those who do not come from the supporters of the elected regional head. The case of rejecting the absence of salat berjamaah in Bandung is one example. It does not mean that rejection does not arise from among the citizens who politically elect the regional head as happened in several cases of rejection in DKI Jakarta. The government's policy of removing salat berjamaah will have the same risk of being the target of error if salat berjamaah are proven to expose victims to the virus.

With these various challenges, not only the substance of the policy material must consider many aspects and various restriction policy options, but policy implementation must also consider many schemes or strategies. The success of this restriction will also require communication, negotiation and lobbying skills that need to be possessed by implementers, especially the COVID-19 Task Force (Satgas Korona-19) in communicating policies with the community at the grassroots or religious figures. Of course, basic knowledge of regional culture and politics is substantial (Muhtada 2020). The chance of the strategy effectiveness for 
involving religious figures from Islamic community organizations such as Nahdlatul Ulama, Muhamadiyah, MUI, Al-Irshad, Al-Washliyah Mathla'ul Anwar, will be high among citizens who culturally affiliated with these organizations (Muhtada, 2020). However, this effort may be less successful if aimed at citizens who do not have a direct affiliation with these organizations.

Not all Muslims in Indonesia feel affiliated with these Islamic organizations. More than half of Muslims admit to not being a member of any mass organization(Ali 2017). To target the second group requires efforts to collaborate with religious figures they follow, who may not be from these religious organizations. By considering the results of studies and surveys that say political affiliation affects citizens' compliance in implementing the COVID-19 prevention protocol, it is also necessary to involve political figures they support. Local government officials need to establish communication with them.

This negotiation does not only come from policymakers and implementers. The COVID-19 outbreak, inevitably, also demands communities in Islam to negotiate their religious rights, particularly the worship right such as salat berjamaah. For example, they can select and negotiate salat berjamaah only for certain salat which are considered more basic and have a higher risk of transmission, such as the salat jumat which only performed once a week. While congregation for the salat lima waktu not implemented. Another possibility is, for example, voluntarily eliminating salat tarawih in congregation due to the frequent gathering, but being able to congregate for the salat idul fitri.

Such negotiations inevitably require frankness of religious understanding of the implementation of Islamic law, which started since the beginning of the COVID-19 outbreak. For example, MUI did it through Fatwa MUI No. 14 Tahun 2020 (MUI Pusat, 2020). This fatwa contains religious views on the four conditions and laws of implementing or leaving salat jumat and replacing them with the salat zuhur at home, along with the withdrawal of the congregation salat lima waktu, tarawih, and Ied at the mosque or other public places. This fatwa based on the concept of achieving the main purpose of religion (al-dharuriyat al-khams) (MUI Pusat 2020). The concept developed by the scholar of the Maliki School, Abu Ishaq al-Shatibi (1388), which refers to the concept of achieving righteousness (maslahah) based on the five basics purposes of Shariah, namely the safety of soul, religion, intellect, lineage, and property (Jahar 2018). In Muhammadiyah, the handling of COVID-19 with the Islamic law approach developed through the exertion of Fikih Kebencanaan (Disaster Fiqh) issued by Majelis Tarjih dan Tajdid Muhammadiyah. This fiqh has been published since 2015 and used again to respond to the spread of COVID-19 (Suyadi et al. 2020, 3).

This strategy of engaging religious figures and religious organizations is not without risks. The first risk is that the government may be tempted to interfere in religious doctrine affair in a diverse community with diverse views. This action can encourage the government to take sides with one view or a particular religious group, thus discriminate against other views or groups. The second risk is the attitude and actions of the government determined based on the religious institution decision, not a government institution, applicable as the basis for 
decisions in government management. So far, the criticism that has often emerged is that the government often uses MUI fatwas as a legal basis. MUI is not a state institution. The attitude to take the views of particular religious organizations such as MUI or other organizations can create the presumption that these institutions are "official religious institutions recognized by the government" have the potential to be discriminatory (Suhadi et al. 2020, 36).

\section{Conclusion}

Like many other countries, the Indonesian government implemented a policy of restricting worship to protect public health. This restriction has a foundation in the laws and regulations in Indonesia, which emphasizes the right to obtain a healthy environment and health services. Apart from the constitution, restrictions on health reasons also regulated in the Human Rights Law. However, this study found that restrictions on salat berjamaah in the early days of the pandemic applied uniformly in the form of the absence of salat berjamaah during the PSBB period. The policy does not provide alternatives such as still allowing salat berjamaah by establishing health protocols. Various policy alternatives are already available in WHO documents on mass meetings and recommendations for handling COVID-19.

These various approaches will better accommodate and provide space for negotiations between the government and those who object or reject the policy. At the same time, policies that provide alternatives are more capable anticipating the politicization of this issue. Negotiations and accommodation do not only occur among policymakers and implementers but also citizens undergo a new era. This study recommends the relevance to develop a Protocol on the Restriction of the Religious or Belief Right in the Pandemic era, to improve the quality of policies on limiting religious right in the COVID-19 outbreak. This protocol is the steps and stages, communication strategies, and negotiation patterns carried out by the central and regional governments in implementing restrictions on the worship right.[]

\section{References}

AAICJ. 1985. "Siracusa Principles on the Limitation and Derogation Provisions in the International Covenant on Civil and Political Rights". American Association for the International Commission of Jurists. http://www.icj.org/wpcontent/uploads/1984/07/Siracusa-principles-ICCPR-legal-submission1985-eng.pdf.

Antaranews.com. 2020. "HNW apresiasi Fatwa MUI tidak generalisasi larangan salat Idul Fitri. Antaranews, 2020. https://www.antaranews.com/berita/1506424/hnw-apresiasi-fatwa-muitidak-generalisasi-larangan-salat-idul-fitri.

Bakar, Z. A. A. 2009. “Perintah dan Manfaat Shalat Berjamaah.” Nu.or.id, March 11, 
2009. https://islam.nu.or.id/post/read/16279/perintah-dan-manfaat-solatberjamaah.

Biro Hukum Provinsi DKI Jakarta. 2020. "Pergub DKI 33 (No 33 tahun 2020; pp. 119)." Biro Hukum Provinsi DKI Jakarta. https://jdih.jakarta.go.id/uploads/default/produkhukum/PERGUB_NO._33_T AHUN_20204.pdf.

CNN Indonesia. 2020. "Surati Jokowi, ICMI Minta Pembatasan Tempat Ibadah Dievaluasi." Cnnindonesia, April 2020. https://www.cnnindonesia.com/nasional/20200414101003-20493320/surati-jokowi-icmi-minta-pembatasan-tempat-ibadah-dievaluasi.

Detik. 2020. "Ini Sejumlah Masjid di Jabar yang Tetap Gelar Salat Jumat.” Detik, March 20, 2020. https://news.detik.com/berita-jawa-barat/d-4946535/inisejumlah-masjid-di-jabar-yang-tetap-gelar-salat-jumat/2.

Dja'far, Alamsyah M., Asfinawati, Febiyonesta, M. Hafiz, M. Isnur, M. S. Azhari, Z. Abidin, S. A. Tardi, T. Sutanto, and R. Ahmad. 2016. Buku Sumber Hak atas Kebebasan Beragama atau Berkeyakinan di Indonesia. Wahid Foundation TIFA Foundation.

Ferrière, A. A. de La. 2020. "Coronavirus: how new restrictions on religious liberty vary across Europe." Theconversation, April 9, 2020. https://theconversation.com/coronavirus-how-new-restrictions-onreligious-liberty-vary-across-europe-135879.

Flood, Colleen M., Vanessa MacDonnell, Bryan Thomas, and Kumanan Wilson. 2020. "Reconciling civil liberties and public health in the response to COVID-19". Canadian Science Publishing. https://www.facetsjournal.com/doi/pdf/10.1139/facets-2020-0070.

George, Cherian. 2017. Pelintiran Kebencian: Rekayasa Ketersinggungan Agama dan Ancamannya bagi Demokrasi. Pusad Paramadina.

Glover, Rebecca E., May C.I. van Schalkwyk, Elie A. Akl, Elizabeth Kristjannson, Tamara Lotfi, Jennifer Petkovic, Mark P. Petticrew, Kevin Pottie, Peter Tugwell, and Vivian Welch. 2020. "A framework for identifying and mitigating the equity harms of COVID-19 policy interventions." Journal of Clinical Epidemiology 128: 35-48. https://doi.org/10.1016/j.jclinepi.2020.06.004.

Hasanuddinali. 2017. "Menakar Jumlah Jamaah NU dan Muhammadiyah. $\begin{array}{lrr}\text { Hasanuddinali, } & \text { January } & 1917 .\end{array}$ https://hasanuddinali.com/2017/01/19/menakar-jumlah-jamaah-nu-danmuhammadiyah/.

Human Right Committee. 1993. General Comment 22 (CCPR/C/21/Rev.1/Add.4, 1993; 1-4).

Istratii, Romina. 2020. "Restricting religious practice in the era of COVID-19: A dewesternised perspective on religious freedom with reference to the case of Greece States of Exception." Political Theology Network. 
https://eprints.soas.ac.uk/32584/1/Restricting religious practice in the era of COVID-19.pdf.

Jahar, A. S. 2018. "Penggunaan Maslahat dalam Fatwa: Menjawab Tantangan Modernitas." In Penggunaan Fatwa dalam Menguatkan Islam Moderat di Indonesia, edited by Syafiq Hasyim and F. S. Alam, 65-77. International Center for Islam and Pluralism (ICIP).

PP 21 Tahun 2020, Pub. L. No. 21 Tahun 2020, 1.2020. https://drive.google.com/uc?export=download\&id=16iguYuED51qKB1_FgFh TMiJVBQBUpJdx.

Kompas. 2020a. "MUI DKI Jakarta Bolehkan Shalat Jumat Dua Gelombang.” Kompas, June 5, 2020. https://megapolitan.kompas.com/read/2020/06/05/10501531/mui-dkijakarta-bolehkan-shalat-jumat-dua-gelombang.

Kompas. 2020b. "Sejumlah Masjid di Kota Makassar Tetap Gelar Shalat Tarawih." Kompas, $\quad$ April 24, 2020. https://regional.kompas.com/read/2020/04/24/11214261/sejumlahmasjid-di-kota-makassar-tetap-gelar-shalat-tarawih.

Kompas. 2020c. "Walau Dilarang, Warga Nekat Panjat Pagar Masjid untuk Shalat Berjemaah." Kompas, April 2020. https://regional.kompas.com/read/2020/04/25/22023951/walau-dilarangwarga-nekat-panjat-pagar-masjid-untuk-shalat-berjemaah

Kuipers, Nicholas, Saiful Mujani, and Thomas Pepinsky. 2020. "Encouraging Indonesians to Pray From Home During the COVID-19 Pandemic." Journal of Experimental Political Science, 1-12. https://doi.org/10.1017/XPS.2020.26.

Kumparan. 2020. "Bubarkan Salat Jumat karena Corona, Camat di Pare-pare Dilaporkan Penodaan Agama." Kumparan, April 29, 2020. https://kumparan.com/kumparannews/bubarkan-salat-jumat-karenacorona-camat-di-pare-pare-dilaporkan-penodaan-agama-1tJdvInPsbl.

Liputan 6. 2020. "Viral Aksi Remaja Pulo Gadung Mengamuk Lantaran Tarawih di Masjid Dikritik.” Liputan 6, April 26, 2020. https://www.liputan6.com/news/read/4238194/viral-aksi-remaja-pulogadung-mengamuk-lantaran-tarawih-di-masjid-dikritik.

Manchin, Gayle, and James W. Carr. 2020. "COVID-19 Symposium: Don't Let Religious Freedom Become a Casualty of Coronavirus." Opiniojuris, 2020. http://opiniojuris.org/2020/04/06/covid-19-symposium-dont-let-religiousfreedom-become-a-casualty-of-coronavirus/.

Marshall, Paul. 2020. "Do Government Restrictions on Larger Church Gathering Violate Religious Freedom?" Hudson, March 27, 2020. https://www.hudson.org/research/15870-do-government-restrictions-onlarger-church-gathering-violate-religious-freedom.

Marvasti, Amir B.. 2004. Qualitative Research in Sociology: An Introduction. London: 
Sage Publication.

Meier, Benjamin Mason, Dabney P. Evans, and Alexandra Phelan. 2020. "Rightsbased approaches to preventing, detecting, and responding to infectious disease outbreaks." In Infectious Diseases in the New Millennium, edited by Mark Eccleston-Turner and Iain Brassington, 217-253. Springer. https://doi.org/10.2139/ssrn.3560669.

Mietzner, Marcus. 2020. "Populist anti-scientism, religious polarisation, and institutionalised corruption: How Indonesia's democratic decline shaped its COVID-19 response." Journal of Current Southeast Asian Affairs 39, no. 2: 227249. https://doi.org/10.1177/1868103420935561

Muhtada, Dani. 2020. "Religion and COVID-19 mitigation." Thejakartapost, March 26, 2020. https://www.thejakartapost.com/academia/2020/03/26/religionand-covid-19-mitigation.html.

MUI Pusat. 2020. "Fatwa No 14 Tahun 2020 - Penyelenggaraan Ibadah dalam Situasi Terjadi Wabah Covid-19.” Mui.or.Id, March 17, 2020. https://mui.or.id/berita/27674/fatwa-penyelenggaraan-ibadah-dalamsituasi-terjadi-wabah-covid-19/.

Mujani, Saiful, and Deni Irvani. 2020. "Sikap dan Perilaku Warga terhadap Kebijakan Penanganan Wabah Covid-19.” Politika: Jurnal Ilmu Politik 11, no. 2: 219-238. https://doi.org/10.14710/politika.11.2.2020.219-238

Organization World Health. 2008. International Health regulations. World Health Organization.

Pabbajah, Mustaqim, Nurhidayat Muhammad Said, Faisal, M. Taufik Hidayat Pabbajah, Hasse Jubba, and Juhansar. 2020. "Deauthorization of the Religious Leader Role in Countering Covid-19: Perceptions and Responses of Muslim Societies on the Ulama's Policies in Indonesia." International Journal of Criminology and Sociology 9: 263-273. https://doi.org/10.6000/19294409.2020.09.25

Plessis, G. A. Du. (2020). COVID-19 and Limitations to the International Right to Freedom of Religion or Belief. Journal of Church and State, 1-29. https://doi.org/10.1093/jcs/csaa082

Rasjid, Sulaiman. 2018. Fiqh Islam (81st ed.). Sinar Baru Algensindo.

Scolnicov, Anat. 2011. The right to religious freedom in international law: between group rights and individual rights. New York: Routledge.

Setara Institute. 2019. Melawan Intoleransi di Tahun Politik: Kondisi Kebebasan Beragama Berkeyakinan dan Pemajuan Toleransi di Indonesia Tahun 2018. https://drive.google.com/file/d/18GlKLonGcWDzQ0hC_yzXfPhr7KGkIc9s/vie w

Spadaro, Alessandra. 2020. "CoviD-19: Testing the limits of human rights." European Journal of Risk Regulation 11, no. 2: 317-325. 
https://doi.org/10.1017/err.2020.27.

Suara. 2020. "Sekelompok Orang Ngamuk di Masjid Raya Bandung karena Tak Boleh Salat Jumat." Jabar.Suara.Com, March 20, 2020. https://jabar.suara.com/read/2020/03/20/164723/sekelompok-orangngamuk-di-masjid-raya-bandung-karena-tak-boleh-salat-jumat.

Suhadi, Bagir, Zainal Abidin, Renata Arianingtyas, and Asfinawati. 2020. "Pembatasan Hak Beragama di Masa Wabah COVID-19." https://crcs.ugm.ac.id/laporancovid/\#.

Suyadi, Zalik Nuryana, and Niki Alma Febriana Fauzi. 2020. “The Fiqh of disaster: The mitigation of covid-19 in the perspective of Islamic educationneuroscience." International Journal of Disaster Risk Reduction 51, December, 101848. https://doi.org/10.1016/j.ijdrr.2020.101848.

Tagar. 2020. “Daftar 18 Wilayah Paling Awal Terapkan PSBB.” Tagar.Id, April 21, 2020. https://www.tagar.id/daftar-18-wilayah-paling-awal-terapkan-psbb.

Tempo. 2020. "Warga Masih Ibadah di Masjid Tambora, Ini Sanksi di PSBB Jakarta." Tempo.Co. https://metro.tempo.co/read/1341356/warga-masih-ibadah-dimasjid-tambora-ini-sanksi-di-psbb-jakarta/full\&view=ok.

Tobroni, F. (2020). Pembatasan Kegiatan Keagamaan Dalam Penanganan Covid-19. Jurnal Komunikasi Hukum (JKH), 6(2), 369-395.

Travica, Bob. 2020. "Containment Strategies for COVID-19 Pandemic." SSRN. http://dx.doi.org/10.2139/ssrn.3604519

United Nation. 1966. "International Covenant on Civil and Political Rights." In International Covenant on Civil and Political Rights.

VOA Indonesia. 2020. "PSBB Tidak Melanggar HAM, Tapi Negara Wajib Pastikan Hak Warga Terpenuhi." Voaindonesia, May 17, 2020. https://www.voaindonesia.com/a/psbb-tidak-melanggar-ham-tapi-negarawajib-pastikan-hak-warga-terpenuhi/5423217.html.

Wahid Foundation. 2020. Tawar-Menawar Kebebasan: Satu Dekade Pemantauan Kemerdekaan Beragama Berkeyakinan Wahid Foundation. Wahid Foundation.

Widyawati, Anis, Rasdi Rasdi, Ridwan Arifin, and Septhian Eka Adiyatma. 2020. "Covid-19 and Human Rights: The Capture of the Fulfilment of Rights During the Covid Outbreaks." Unnes Law Journal 6, no. 2: 259-286.

Wiratraman, Herlambang Perdana. 2020. "Does Indonesian COVID-19 Emergency Law Secure Rule of Law and Human Rights?." JSEAHR 4, no. 1: 306334. https://doi.org/10.19184/jseahr.v4i1.18244

World Health Organization. 2015. Public health for mass gatherings: key considerations. World Health Organization.

World Health Organization. 2020a. "Key planning recommendations for mass gatherings in the context of the current COVID-19 outbreak: interim 
guidance." World Health Organization, February 14, 2020. https://apps.who.int/iris/bitstream/handle/10665/331004/WHO-2019-

nCoV-POEmassgathering-2020.1-eng.pdf.

World Health Organization. 2020b. "Situation by Country, Territory \& Area." Www.Covid19.Who.Int. https://covid19.who.int/table.

Yahman, and Aziz Setyagama. 2020. "Legal Problematics Against Policy Covid-19 in Indonesia." PalArch's Journal of Archaeology of Egypt/Egyptology 17, no. 4: 1022-1038. https://doi.org/10.48080/jae.v17i4.555.

\section{Author Biography}

Alamsyah M. Dja'far is a Master candidate at School Government and Public Policy Indonesia. For nearly 10 years, he has been involved in working on issues of freedom of religion and belief and advocating for the rights of religious minorities in Indonesia at Wahid Foundation. Since 2015, he has focused his research on prevention and countering violent extremism. His other areas of specialization include peace and religious intolerance.

Email: a.djafar@sgpp.ac.id 